\title{
Management Instruments in the Emergency Department
}

\author{
Barbara Christine Hogan \\ Geesthacht Medical Centre, Hamburg, Germany
}

Cite this article as: Hogan BC. Management Instruments in the Emergency Department. Eurasian J Emerg Med. $2018 ; 17$ (3): $90-2$.

\begin{abstract}
Different management techniques need to be used to solve the special problems and challenges faced in emergency departments (EDs). These include SWOT (strengths, weaknesses, opportunities, and threats) analysis, lean management, process management, change management, and syntegration. A successful leader of an ED needs to use elements from industrial management techniques, especially those involving work that takes place in a constant flow and does not stop. A process of strategic reorganization may be needed.
\end{abstract}

Keywords: Emergency department, management, processes, lean management, leadership

\section{Introduction}

Different management techniques need to be used to solve the special problems and challenges faced in emergency departments (EDs). These include SWOT (strengths, weaknesses, opportunities, and threats) analysis, lean management, process management, change management, and syntegration (1-6). A successful leader of an ED needs to use elements from industrial management techniques, especially those involving work that takes place in a constant flow and does not stop (7). A process of strategic reorganization may be needed.

The process should start with a SWOT analysis of the strengths, weaknesses, opportunities, and threats faced by the ED (1).

This should also include an analysis of the hospital itself. A common problem with the hospital structure is an inefficient "silo" or "island" command and control structure. This means that other specialty medical departments operate alone, focusing on their own work, ignoring the other departments, and not coordinating activities. These operational silos or islands can result in a huge loss of efficiency $(6,7)$.

A detailed examination must also be performed of ED strategic goals, current working practices, interfaces between the ED and other departments, staffing, and resources.
A common challenge expected is creating ED working systems in which work flows. This is important to prevent long waiting times and to deal with the large numbers of patients who need medical care. The science of creating a flow of work is a part of the management tool called lean management. This is a science that is used in manufacturing industries, including the automobile industry (8). Sometimes, doctors do not like being compared with workers from the automobile industry. But the leader of an ED must have an open mind and be ready to learn from even non-medical science.

As an example of lean management in EDs, I will describe the First View concept $(5,6)$ that I implemented in Germany.

The patient arrives and undergoes triage by a specially trained nurse. In the First View concept (7), a senior physician then makes an initial examination of the patient in a first view. After this provisional diagnosis of the patient, the senior physician then delegates systematic diagnostic and treatment work to junior physicians and laboratories, etc.

The initial treatment and diagnostics tasks are performed while the laboratory tests are ordered. When this process is completed, the senior physician then reviews the case and makes a decision about admitting the patient to an in-house medical department, transferring to intermediate care, or discharging home.

This study was presented in the $5^{\text {th }}$ International Critical Care and Emergency Medicine Congress (EPAT), April 2018, Antalya.

Corresponding Author: Barbara Christine Hogan e-mail: drhogan@online.de

Received: 10.05.2018 • Accepted: 04.06.2018

(C) Copyright 2018 by Emergency Physicians Association of Turkey - Available online at www.eajem.com

DOI: 10.5152/eajem.2018.36854 
The key is that different types of work continue constantly and simultaneously on large numbers of patients. The goal is that working processes should not stop while another work is being carried out.

To deal with the large numbers of patients with minor illnesses or injuries, a Fast Track Unit was created. It comprised an experienced physician who was qualified to not only quickly treat small ailments but also identify patients with serious illnesses who were not recognized by the triage nurse.

Such processes must be supported by intelligent information technology to give an overview of the status of each patient and to reduce the time needed for administrative tasks to a minimum. IT systems are available that give an overview of where patients are, how long they have been waiting, and what processes they are waiting for or are undergoing $(8,6)$.

The ED is a very complex organization. But the leader needs to think in simple terms, using techniques from industry, especially automobile production, to assess resources (9).

In industry, these terms are hardware, software, peopleware, and brainware (6).

Hardware is the hard equipment and buildings that the ED possesses. Software is not computer software but the professional skills of the ED personnel.

Peopleware is naturally the doctors, nurses, and other support personnel.

Brainware is the benefit the department has created; it is the ED's expertise, capability, and experience that it has created by working together.

Probably, the tool of total quality management $(10,11)$ will also be needed to assess quality, to achieve mastery through perfection in detail, to achieve standards of care, and to recognize errors and create systems to avoid them.

Introducing a change is a management technique that is common in other industries. The ED leader must consider the expertise developed when other industries underwent changes; this is known as change management.

Announcing that a change will take place, either inside the ED or in the hospital itself, is often only of little use. There could be passive and active resistance to plans from an ED leader for a change, both inside the ED and in other hospital departments. Instead, change management is needed. This is the science of introducing a change including when change may be resisted.

The change management tool requires clear leadership. The playing field and rules must be clearly defined. A detailed analysis must be made of a working process and everyone and everything involved in it. A detailed plan must then be made of the change. The process must be systematic and not intuitive, like in the additional management technique of project management.
One or many projects should be created in detail to define and implement the change. Each stage of change implementation is made clear, and the role of every personnel involved is made transparent. The fear of change can be removed by understanding why and what change is needed and that many things in the department are changing.

A clear time schedule is also created for the preparation and implementation of the change process. This gives the ED leader a detailed overview of the change process: its progress, lack of progress, and causes of delays.

The goal should be to establish the ED as a center of excellence that ultimately helps the hospital to achieve its strategic goals.

Emergency departments and emergency physicians work on an orientation on function. This means faster work, with better organization than some other hospital departments that operate as silos or operational islands.

An answer to solve the problem of working with other departments is the management tool of syntegration presented by Anthony Stafford Beer (1). Syntegration means synergy and integration. This means creating a close link between the ED and other hospital departments by making use of networking, complexity, agility, communications, empowerment, self-reflection, and creative tensions.

An ED can create benefit for all involved in the hospital and for patients (9). It can become a center of excellence for the hospital, moving away from being purely regarded as a cost center to becoming a competence center that establishes the treatment patterns and helps steer the hospital to strategic success.

By implementing all these management tools, the ED as a corporate center of excellence can create added, shared value. The ED moves from being a cost center to being a profit and competence center inside the hospital network $(6,10,12)$.

\section{Conclusion}

A mix of different management techniques must be used to solve the special problems and challenges faced in EDs. No single technique is enough. A successful leader of an ED needs to use elements from industrial management techniques, especially those involving work that takes place in a constant flow and does not stop. Techniques must also be used for change management and for Syntegration with the aim of making the ED a centre of corporate excellence.

Peer-review: Externally peer-reviewed.

Conflict of Interest: The author has no conflict of interest to declare.

Financial Disclosure: The author declared that this study has received no financial support.

\section{References}

1. Brachmann HB. SWOT Analyse einer Zentralen Notaufnahme mit Analyse der Erfolgspotentiale. Notf Rett Med. 2009; 22: 256-60. 
2. Dickson E, Anguelov Z, Vetterick D, Eller A, Singh S. Use of Lean in the Emergency Department: A Case Series of 4 Hospitals. Ann Emerg Med. 2009; 54: 504-10. [CrossRef]

3. Lean Hospital. LMI, Lean Management Institut, GmbH, Steinbachstr. 25, RWTH Aachen, 52074 Aachen. Available from: URL: :http://www. lean-management-institut.de/index.php?id=100

4. Beer, ST. Syntegration as a renascence of the ancient Greek agora in present-day organisations. JUKM. 2005; 1: 59-66.

5. Hogan B, Singh M, Rache C. Patientenzufriedenheit und Wartezeiten. In: Von Eiff W, Dodt C, Brachmann M, Fleischmann H, editors. Management der Notaufnahme. 2011.p.298-307.

6. Rasche C, Margaria T, Braun von Reinersdorff A. Value Delivery Through ITbased Healthcare Architectures: Towards a Competence-based View of Services. In: Stephan M, Kerber W, Kessler T, Lingenfelder M, editors. Towards a Competence-based View of Services. Switzerland: Springer; 2010.p.417-43.

7. Hogan B, Rasche $C$, von Reinersdorff AB. The First View Concept: introduction of industrial flow techniques into emergency medicine organization. Eur J Emerg Med. 2012; 19: 136-9. [CrossRef]
8. Bernstein SL, Aronsky D, Duseja R, Epstein S, Handel D, Hwang U,et al. The effect of emergency department crowding on clinically oriented outcomes. Acad Emerg Med. 2009; 16: 1-10. [CrossRef]

9. Hogan, B.; Braun von Reinersdorff, A. \& Rasche, C. Value creation in emergency departments: In search of sustainable management paradigms for medicine. Italian Journal of Emergency Medicine. 2012: 1369.

10. Braun von Reinersdorff A, Rasche C. Mobilisierung strategischer und operative Leistungsreserven im Krankenhaus - Gestaltungsfelder und Grenzen der Service-Industrialisierung In: Bouncken R, Pfannstiel MA, editors. Dienstleistungsmanagement im Krankenhaus. Wiesbaden: Springer; 2004.p.29-57.

11. Collins KF, Muthusamy SK. Applying the Toyota Production System to a Healthcare Organization: A Case Study on a Rural Community Healthcare Provider. Quality Management Journal. 2007; 14: 1-10. [CrossRef]

12. Dickson EW, Anguelov Z, Vetterick D, Eller A, Singh S. Use of Lean in the Emergency Department: A Case Series of 4 Hospitals. Ann Emerg Med. 2009; 54: 504-10. [CrossRef] 